\title{
Condition and Feeding of Greenland Halibut (Reinhardtius hippoglossoides) in the North Atlantic with Emphasis on the Flemish Cap
}

\author{
Esther Román, Concepción González and Xabier Paz \\ Centro Oceanográfico de Vigo (I. E. O.) \\ P. O. Box 1552, 36200 Vigo, Spain
}

Román, E., C. González, and X. Paz. 2007. Condition and Feeding of Greenland Halibut (Reinhardtius hippoglossoides) in the North Atlantic with Emphasis on the Flemish Cap. J. Northw. Atl. Fish. Sci., 37: 165-179. doi:10.2960/J.v37.m557

\begin{abstract}
The Relative Condition Factor of Greenland halibut (Reinhardtius hippoglossoides) was analysed for seasonal, annual and geographical variability. Sampling covered commercial fishing and scientific surveys in three areas of the North Atlantic (NAFO Divisions 3M and 3LNO, and ICES Division IIb), comprising a total of 64984 individuals from 1992 to 2003. Several data sets were established in order to carry out the comparisons: individuals as a whole; by sex - females and males separately; and by areas - each area independently. Condition showed significant differences with regard to the area, season, size range and sex, but it was not always significant among interactions of these factors. Individuals from the Northeast Atlantic had better condition, while those in the Northwest Atlantic suffered a notable fall in condition throughout the studied period, mainly in Flemish Cap. Condition was lightly superior in females, regarding size. A clear increment in the feeding intensity appeared when the condition diminished. When the total weight is used to calculate the condition, more remarkable differences could be expected because this index is sensitive to the gonad weight; in this respect, adult females showed more marked differences. Moreover, the complex maturity schedule and variable maturity at size would contribute to find misleading differences. Feeding habits of Greenland halibut were studied in the same areas based on a sample of 19001 fish. Feeding intensity was the higher on the Flemish Cap, where the main preys were Pandalus borealis, Sebastes spp. and Serrivomer beani. P. borealis predation increased in the late 1990s. Diet was piscivorous in Div. 3LNO and Div. IIb as well, mainly based on Mallotus villosus and Micromesistius poutassou, respectively. Cannibalism and offal consumption was remarkable in Svalbard (ICES Div. IIb). Fish predation increased when predator size increased. Molluscs took an important place in the diet of intermediate sizes in Div. 3LNO and IIb. Similar diet pattern for both sexes was observed.
\end{abstract}

Key words: condition factor, Flemish Cap, Greenland halibut, North Atlantic, Reinhardtius hippoglossoides

\section{Introduction}

Greenland halibut (Reinhardtius hippoglossoides) is an economically and ecologically important flatfish that inhabits both sides in the North Atlantic. The Greenland halibut in NAFO Subareas 0, 1, 2 and Div. 3KLMNO is considered the same complex stock. The exploitable biomass was reduced to low levels in 1995-97. It increased during 1998-2000 due to the decrease in catches and the improvement of the recruitment, and then fell again during the period 2003-2004 to the lowest values in the series (NAFO, MS 2005). Survey biomass indices in the Flemish Cap (NAFO Div. 3M) maintained a continu- ous increase to a peak in 1998 and decreased since then (Casas, MS 2004). The stock in the Svalbard area (ICES Div. IIb) is below historical levels (ICES, MS 2004; Paz et al., MS 2004).

Condition indices provide a useful assessment of the physiological well-being of fishes and provide an indirect means to evaluate ecological relations and the effects of management strategies (Murphy et al., 1991). Studies have demonstrated that these indices are a measure of the energy reserves of fishes and their relationships with the environmental, maturity, feeding or parasitic conditions (Costopoulos and Fonds, 1989). 
The relationships among condition, biomass and natural mortality has been analysed in Atlantic cod (Gadus morhua) (Lambert and Dutil, 1997a, b). Also the decrease of the reproductive investment could affect the reproductive potential and recruitment (Lambert and Dutil, 2000). Junquera et al. (1999) analysed the possible compensatory effect on the reproductive and growth of the Greenland halibut in Northwest Atlantic observing that the condition factor had remained almost invariable throughout the period 1991-1997, in spite of being subjected to a strong exploitation.

The condition and feeding habits of Greenland halibut in three areas of the North Atlantic, NAFO Divs. 3M and
3LNO, and Svalbard Area (ICES Div. IIb), from 1992 to 2003 were examined in this study.

\section{Material and Methods}

A total of 64984 individual Greenland halibut (Reinhardtius hippoglossoides) from the Northwest Atlantic were analysed from scientific and commercial surveys during the period 1992-2003 (Tables 1 and 2). The surveys were: the summer EU Bottom Trawl Survey of Flemish Cap (NAFO Div. 3M) (Casas, MS 2004), the spring Spanish Survey "Platuxa" in NAFO Div. 3NO (González Troncoso et al., MS 2004), the summer Spanish Survey "3L-Fletán Negro" in the Flemish Pass; and the

TABLE 1. Number of individuals of $R$. hippoglossoides sampled for relative condition factor study by area (NAFO Divs. 3LNO and 3M; ICES Div. IIb), year (1992-2003) and size range.

\begin{tabular}{|c|c|c|c|c|c|c|c|c|c|c|c|c|c|c|}
\hline \multirow[b]{2}{*}{ Area } & \multirow{2}{*}{$\begin{array}{l}\text { Size } \\
\text { range } \\
(\mathrm{cm})\end{array}$} & \multicolumn{12}{|c|}{ Year } & \multirow[b]{2}{*}{ Total } \\
\hline & & 1992 & 1993 & 1994 & 1995 & 1996 & 1997 & 1998 & 1999 & 2000 & 2001 & 2002 & 2003 & \\
\hline \multirow[t]{9}{*}{$3 \mathrm{M}$} & $10-19$ & & 12 & 31 & 56 & 80 & 123 & 106 & 25 & 171 & 113 & 119 & 127 & 963 \\
\hline & $20-29$ & 53 & 134 & 109 & 101 & 135 & 227 & 176 & 85 & 53 & 129 & 138 & 108 & 1448 \\
\hline & $30-39$ & 59 & 159 & 306 & 146 & 168 & 341 & 669 & 278 & 278 & 464 & 475 & 208 & 3551 \\
\hline & $40-49$ & 429 & 379 & 475 & 250 & 308 & 357 & 679 & 295 & 432 & 1977 & 1866 & 673 & 8120 \\
\hline & $50-59$ & 252 & 222 & 184 & 112 & 143 & 175 & 258 & 129 & 199 & 1403 & 1379 & 591 & 5047 \\
\hline & $60-69$ & 33 & 17 & 24 & 26 & 12 & 22 & 16 & 12 & 13 & 284 & 373 & 97 & 929 \\
\hline & $70-79$ & 4 & 1 & & 1 & 2 & 2 & 1 & 1 & & 80 & 98 & 41 & 231 \\
\hline & $80-89$ & & & & & & & & & & 35 & 24 & 12 & 71 \\
\hline & Total & 830 & 924 & 1129 & 692 & 848 & 1247 & 1905 & 825 & 1146 & 4485 & 4472 & 1857 & 20360 \\
\hline \multirow[t]{9}{*}{$3 \mathrm{LNO}$} & $10-19$ & & & & 3 & 16 & 101 & 35 & 78 & 49 & 133 & 167 & 329 & 911 \\
\hline & $20-29$ & & & & 47 & 187 & 782 & 344 & 172 & 99 & 238 & 249 & 425 & 2543 \\
\hline & $30-39$ & & & & 26 & 164 & 697 & 254 & 110 & 155 & 1847 & 1306 & 957 & 5516 \\
\hline & $40-49$ & & & & 2 & 152 & 452 & 148 & 87 & 226 & 3796 & 3081 & 1119 & 9063 \\
\hline & $50-59$ & & & & & 88 & 249 & 159 & 70 & 149 & 1889 & 2208 & 800 & 5612 \\
\hline & $60-69$ & & & & & 39 & 135 & 123 & 61 & 136 & 519 & 775 & 147 & 1935 \\
\hline & $70-79$ & & & & & 10 & 51 & 69 & 39 & 80 & 183 & 184 & 52 & 668 \\
\hline & $80-89$ & & & & & 8 & 11 & 28 & 17 & 31 & 97 & 46 & 11 & 249 \\
\hline & Total & & & & 78 & 664 & 2478 & 1160 & 634 & 925 & 8702 & 8016 & 3840 & 26497 \\
\hline \multirow[t]{10}{*}{$\mathrm{IIb}$} & $20-29$ & & & & 2 & & 10 & 28 & 19 & 17 & 39 & 44 & 35 & 194 \\
\hline & $30-39$ & & & & 92 & & 496 & 159 & 421 & 197 & 419 & 419 & 351 & 2554 \\
\hline & $40-49$ & & & & 2103 & & 830 & 278 & 736 & 233 & 541 & 571 & 405 & 5697 \\
\hline & $50-59$ & & & & 1185 & & 689 & 273 & 709 & 230 & 531 & 608 & 408 & 4633 \\
\hline & $60-69$ & & & & 540 & & 381 & 159 & 358 & 150 & 379 & 510 & 336 & 2813 \\
\hline & $70-79$ & & & & 202 & & 248 & 118 & 126 & 106 & 186 & 237 & 201 & 1424 \\
\hline & $80-89$ & & & & 16 & & 76 & 45 & 39 & 94 & 114 & 130 & 166 & 680 \\
\hline & 90-99 & & & & 2 & & 13 & 10 & 4 & 21 & 19 & 30 & 33 & 132 \\
\hline & Total & & & & 4142 & 0 & 2743 & 1070 & 2412 & 1048 & 2228 & 2549 & 1935 & 18127 \\
\hline & Total & 830 & 924 & 1129 & 4912 & 1512 & 6468 & 4135 & 3871 & 3119 & 15415 & 15037 & 7632 & 64984 \\
\hline
\end{tabular}


TABLE 2. Number of individuals of $R$. hippoglossoides sampled by area (NAFO Divs. 3LNO and 3M; ICES Div. IIb), year (1992-2003) and season.

\begin{tabular}{|c|c|c|c|c|c|c|c|c|c|c|c|c|c|c|}
\hline \multirow[b]{2}{*}{ Area } & \multirow[b]{2}{*}{ Season } & \multicolumn{12}{|c|}{ Year } & \multirow[b]{2}{*}{ Total } \\
\hline & & 1992 & 1993 & 1994 & 1995 & 1996 & 1997 & 1998 & 1999 & 2000 & 2001 & 2002 & 2003 & \\
\hline \multirow[t]{4}{*}{$3 \mathrm{M}$} & Spring & & & & & & & & & & 696 & 629 & 935 & 2260 \\
\hline & Summer & 830 & 924 & 1129 & 692 & 848 & 1247 & 1905 & 825 & 1146 & 1203 & 2741 & 922 & 14412 \\
\hline & Autumn & & & & & & & & & & 1441 & 561 & & 2002 \\
\hline & Winter & & & & & & & & & & 1145 & 541 & & 1686 \\
\hline \multirow[t]{4}{*}{$3 \mathrm{LNO}$} & Spring & & & & 78 & 664 & 2478 & 1160 & 634 & 925 & 1699 & 1338 & 1803 & 10779 \\
\hline & Summer & & & & & & & & & & 1659 & 1604 & 2037 & 5300 \\
\hline & Autumn & & & & & & & & & & 2706 & 2470 & & 5176 \\
\hline & Winter & & & & & & & & & & 2638 & 2604 & & 5242 \\
\hline \multirow[t]{3}{*}{$\mathrm{IIb}$} & Summer & & & & 4142 & & & & & & & 6 & & 4148 \\
\hline & Autumn & & & & & & 2743 & 1070 & 2412 & 1048 & 2228 & 2352 & 1758 & 13611 \\
\hline & Winter & & & & & & & & & & & 191 & 177 & 368 \\
\hline
\end{tabular}

autumn Spanish Survey "Fletán Ártico" in Svalbard ICES Div. IIb (Paz et al, MS 2004). Commercial data were available for the Spanish bottom trawl fishery for Greenland halibut in NAFO (1992-2003), the Spanish pair trawl fishery for Atlantic cod in the Svalvard area, and the Spanish bottom trawl fishery for northern shrimp (Pandalus borealis) also in Svalvard area. Data from the Pilot Action of Experimental Fishing carried out in the Sea of Barents-Svalbard (ICES, Divs. I and IIb) targeting American plaice (Hippoglossoides platessoides) in 1995 were also included (Durán and Román, MS 2000). The same biological data were used to calculate the condition as well as the parameters of the length-weight relationship.

The biological sampling was carried out onboard, and the data collected for each individual fish were: length (TL to the nearest $\mathrm{cm}$ below), sex, maturity stage (immature, maturing, spawning and post-spawning), weight $(\mathrm{g})$ and stomach repletion (empty, fullness). The individuals were compiled in size ranges of $10 \mathrm{~cm}$ each (starting with the 10-19 $\mathrm{cm}$ group) (Table 1). Maturity stages were determined by macroscopic analysis. In some cases, individuals bigger than $100 \mathrm{~cm}$ were not considered due to low sample size.

Data were grouped by seasons (Table 2). Data from March to May are referred as spring; June-August as summer; September-November as autumn; and December-February as winter. The annual cycle was incomplete in ICES Div. IIb because of scarce data. The inter-annual comparisons were only made when at least, a two year series for the same season was available. Data from Divi- sions 3LNO were studied as a whole and separated from those of Div. 3M.

The condition index provides a useful assessment of the 'plumpness' and physiological well-being of fishes. Relative Condition Factor $\left(K_{r}\right)$ is calculated to compare fishes of the same species of different lengths, sex, locations and years (Le Cren, 1951), from

$$
K_{r}=W_{i} / W_{i}^{\prime}
$$

where $W_{i}$ and $W_{i}^{\prime}$ are, respectively, the observed and expected weight in $\mathrm{g}$ of fish $i$.

Expected weight $\left(W_{i}^{\prime}\right)$ is calculated from

$$
W_{i}^{\prime}=a L^{b}
$$

where $L$ is fish length in $\mathrm{cm}$. Parameters $a$ and $b$ of this relationship were calculated as required in each case: for the whole set, by separate sex and/or by areas.

A general linear model (GLM) was used to analyze differences among groups.

Greenland halibut feeding habits were studied using the same research surveys (Table 3 ). In each haul, a maximum of 10 stomachs from each $10 \mathrm{~cm}$ length group were analysed. Fish whose stomachs were everted or contained prey ingested in the fishing gear were discarded. Fish showing total or partial regurgitation were taken into account to estimate the emptiness indices. The method used has been the same since 1993 (Rodríguez-Marín et al., MS 1994). 
Table 3. Characteristics of individuals of $R$. hippoglossoides sampled in the feeding study by area (NAFO Divs. 3LNO and 3M; ICES Div. IIb) and year (1993-2003). \% FI = Feeding intensity; No. Reg. = Number of regurgitated stomachs.

\begin{tabular}{|c|c|c|c|c|c|c|c|c|c|c|c|}
\hline Survey & Division & Year & $\begin{array}{l}\text { No. } \\
\text { Empty }\end{array}$ & $\begin{array}{l}\text { No. } \\
\text { Full }\end{array}$ & $\begin{array}{l}\text { No. } \\
\text { Reg. }\end{array}$ & Total & $\% \mathrm{FI}$ & $\begin{array}{l}\text { Size range } \\
\quad(\mathrm{cm})\end{array}$ & $\begin{array}{l}\text { Depth range } \\
(\mathrm{m})\end{array}$ & $\begin{array}{l}\text { No. of } \\
\text { hauls }\end{array}$ & $\begin{array}{c}\text { No. Prey } \\
\text { items }\end{array}$ \\
\hline "Flemish Cap" & $3 \mathrm{M}$ & 1993 & 138 & 392 & 4 & 534 & 74.2 & $11-79$ & $221-730$ & 50 & 43 \\
\hline "Flemish Cap" & $3 \mathrm{M}$ & 1996 & 401 & 633 & 0 & 1034 & 61.2 & $12-82$ & $231-670$ & 54 & 53 \\
\hline "Flemish Cap" & $3 \mathrm{M}$ & 1997 & 442 & 649 & 3 & 1094 & 59.6 & $13-81$ & $219-679$ & 51 & 59 \\
\hline "Flemish Cap" & $3 \mathrm{M}$ & 1998 & 360 & 619 & 23 & 1002 & 64.1 & $14-79$ & $203-709$ & 56 & 59 \\
\hline "Flemish Cap" & $3 \mathrm{M}$ & 1999 & 486 & 746 & 1 & 1233 & 60.6 & $9-70$ & $223-709$ & 58 & 56 \\
\hline "Flemish Cap" & $3 \mathrm{M}$ & 2000 & 258 & 509 & 15 & 782 & 67.0 & $14-63$ & $194-555$ & 45 & 43 \\
\hline "Flemish Cap" & $3 \mathrm{M}$ & 2001 & 557 & 720 & 0 & 1277 & 56.4 & $13-66$ & $166-708$ & 66 & 57 \\
\hline "Flemish Cap" & $3 \mathrm{M}$ & 2002 & 305 & 669 & 2 & 976 & 68.8 & $12-66$ & $160-730$ & 58 & 52 \\
\hline "Flemish Cap" & $3 \mathrm{M}$ & 2003 & 410 & 589 & 0 & 999 & 59.0 & $12-68$ & $83-688$ & 88 & 48 \\
\hline "Platuxa" & $3 \mathrm{NO}$ & 2002 & 488 & 367 & 0 & 855 & 42.9 & $9-89$ & $68-1377$ & 72 & 30 \\
\hline "Platuxa" & $3 \mathrm{NO}$ & 2003 & 535 & 459 & 0 & 994 & 46.2 & $8-95$ & $43-1449$ & 75 & 26 \\
\hline "3L - Fletan negro" & $3 \mathrm{~L}$ & 2003 & 314 & 219 & 0 & 533 & 41.1 & $10-88$ & $132-1087$ & 31 & 22 \\
\hline "Fletán Ártico" & II b & 1997 & 1644 & 531 & 0 & 2175 & 24.4 & $25-102$ & $543-1312$ & 99 & 32 \\
\hline "Fletán Ártico" & II $b$ & 2000 & 1414 & 321 & 0 & 1735 & 18.5 & $15-97$ & $484-1171$ & 71 & 30 \\
\hline "Fletán Ártico" & II b & 2001 & 1686 & 294 & 0 & 1980 & 14.8 & $21-101$ & $563-1123$ & 26 & 25 \\
\hline "Fletán Ártico" & $\mathrm{II} \mathrm{b}$ & 2002 & 1376 & 422 & 0 & 1798 & 23.5 & $17-103$ & $581-1158$ & 62 & 39 \\
\hline \multirow[t]{3}{*}{ TOTAL } & Div 3M & $1993-2003$ & 3357 & 5526 & 48 & 8931 & 62.4 & $5-60$ & $130-639$ & 526 & 70 \\
\hline & Div. 3LNO & $2002-2003$ & 1337 & 1045 & 0 & 2382 & 43.9 & $5-72$ & $39-1460$ & 178 & 50 \\
\hline & Div. II b & $1997-2002$ & 6120 & 1568 & 0 & 7688 & 20.4 & $15-103$ & $484-1312$ & 258 & 57 \\
\hline
\end{tabular}

Data taken for each predator were: total length (nearest $\mathrm{cm}$ below); volume of the stomach content in $\mathrm{cm}^{3}$, measured by using a trophometer (Olaso, 1990); percentage of each prey in the total volume; and number of each prey. Prey were identified by species whenever the digestion stage allowed it, or to the lowest possible taxonomic level.

Feeding Intensity Index $(F I)$ was calculated to analyse te percentage of individuals with stomach content, from

$$
F I=100 n / N
$$

where $n$ is the number of individuals with stomach contents and $N$ is the total number of individuals sampled.

The importance of each prey taxa $(V p)$ was evaluated using the percentage by volume, from

$$
V p=100 v / V
$$

where $v$ is volume of a determined prey, and $V$ is the total volume of stomach contents. The volumetric method overvalues the importance of large organisms (Hyslop, 1980).

\section{Results}

\section{Condition}

In all areas. Relative condition factor showed significant differences with respect to area, year, season, size range and sex, but not all interactions between factors were significant (Table 4A). Condition decreased in the three areas, particularly in the NAFO area (Divisions 3LNO and 3M), throughout the considered period. In Flemish Cap (Division 3M), condition reached a minimum between 1998 and 2000; condition in summer and estimated biomass (Casas and González Troncoso, MS 2003) presented a significant negative correlation. On the other hand, in Div. 3LNO, condition recovered from 1998 to 2000, but the general trend was also descending. Condition and estimated biomass (González Troncoso et al., MS 2004) were significant and positively correlated during the spring period. Individuals in Svalbard area (Division IIb) had better condition, so much in autumn as in the 
TABLE 4. Tests of between-subjects effects of $R$. hippoglossoides sampled. $\mathrm{df}=$ degrees of freedom $(n$,error)

\begin{tabular}{|c|c|c|c|c|c|c|c|}
\hline \multicolumn{4}{|c|}{ A.- Condition data of the individuals of the three areas } & \multicolumn{4}{|c|}{ B.- Condition data of the females of the three areas } \\
\hline Source & $F$ & $\begin{array}{c}\mathrm{df} \\
(n, 64421)\end{array}$ & Sig. & Source & $F$ & $\begin{array}{c}\mathrm{df} \\
(n, 37575)\end{array}$ & Sig. \\
\hline Area & 3.6 & 2 & $\mathrm{p} \leq 0.05$ & Area & 9.8 & 2 & $\mathrm{p} \leq 0.0001$ \\
\hline Year & 7.4 & 11 & $\mathrm{p} \leq 0.0001$ & Year & 13.5 & 11 & $\mathrm{p} \leq 0.0001$ \\
\hline Season & 3.4 & 3 & $\mathrm{p} \leq 0.05$ & Season & 4.8 & 3 & $\mathrm{p} \leq 0.01$ \\
\hline Size range & 14922 & 8 & $\mathrm{p} \leq 0.0001$ & Size range & 83.2 & 8 & $\mathrm{p} \leq 0.0001$ \\
\hline Sex & 27.3 & 1 & $\mathrm{p} \leq 0.0001$ & $\begin{array}{l}\text { Area } \times \text { Year } \times \text { Season } \times \\
\text { Size range }\end{array}$ & 3.4 & 16 & $\mathrm{p} \leq 0.0001$ \\
\hline Area $\times$ Year $\times$ Season $\times$ Size range & 2.0 & 16 & $\mathrm{p} \leq 0.01$ & & & & \\
\hline Area $\times$ Year $\times$ Season $\times$ Sex & 2.5 & 4 & $\mathrm{p} \leq 0.05$ & & & & \\
\hline \multicolumn{4}{|c|}{ C.- Condition data of the males of the three areas } & \multicolumn{4}{|c|}{ D.- Condition data of the individuals of Div. $3 \mathrm{M}$} \\
\hline Source & $F$ & $\begin{array}{c}\mathrm{df} \\
(n, 13710)\end{array}$ & Sig. & Source & $F$ & $\begin{array}{c}\mathrm{df} \\
(n, 20137)\end{array}$ & Sig. \\
\hline Area & 10.1 & 2 & $\mathrm{p} \leq 0.0001$ & Sex & 30.1 & 1 & $\mathrm{p} \leq 0.0001$ \\
\hline Year & 12.8 & 11 & $\mathrm{p} \leq 0.0001$ & Season & 11.3 & 3 & $\mathrm{p} \leq 0.0001$ \\
\hline Season & 26.6 & 3 & $\mathrm{p} \leq 0.0001$ & Size range & 54.4 & 7 & $\mathrm{p} \leq 0.0001$ \\
\hline Size range & 4.7 & 4 & $\mathrm{p} \leq 0.001$ & Year & 11.3 & 11 & $\mathrm{p} \leq 0.0001$ \\
\hline Area $\times$ Season $\times$ Size range & 4.9 & 4 & $\mathrm{p} \leq 0.001$ & Sex $\times$ Size range $\times$ Year & 2.5 & 53 & $\mathrm{p} \leq 0.0001$ \\
\hline Year $\times$ Season $\times$ Size range & 9.1 & 11 & $\mathrm{p} \leq 0.0001$ & Season $\times$ Size range $\times$ Year & 2.5 & 17 & $\mathrm{p} \leq 0.001$ \\
\hline \multicolumn{4}{|c|}{ E.- Condition data of the individuals of Divs. $3 \mathrm{LNO}$} & \multicolumn{4}{|c|}{ F.- Condition data of the individuals of Div. IIb } \\
\hline Source & $F$ & $\begin{array}{c}\mathrm{df} \\
(n, 26292)\end{array}$ & Sig. & Source & $F$ & $\begin{array}{c}\mathrm{df} \\
(n, 17992)\end{array}$ & Sig. \\
\hline Sex & 10.4 & 1 & $\mathrm{p} \leq 0.001$ & Sex & 35.3 & 1 & $\mathrm{p} \leq 0.0001$ \\
\hline Season & 4.6 & 3 & $\mathrm{p} \leq 0.01$ & Season & 0.3 & 2 & $\mathrm{p}>0.05$ \\
\hline Size range & 54.2 & 7 & $\mathrm{p} \leq 0.0001$ & Size range & 26.0 & 7 & $\mathrm{p} \leq 0.0001$ \\
\hline Year & 14.2 & 8 & $\mathrm{p} \leq 0.0001$ & Year & 8.9 & 7 & $\mathrm{p} \leq 0.0001$ \\
\hline Sex $\times$ Season $\times$ Year & 3.2 & 4 & $\mathrm{p} \leq 0.05$ & Sex $\times$ Size range $\times$ Year & 2.3 & 28 & $\mathrm{p} \leq 0.0001$ \\
\hline Season $\times$ Size range $\times$ Year & 7.3 & 21 & $\mathrm{p} \leq 0.0001$ & Season $\times$ Size range $\times$ Year & 3.0 & 6 & $\mathrm{p} \leq 0.01$ \\
\hline
\end{tabular}

whole year, but the general trend showed slight decrease, especially for males. Condition and estimated biomass (Paz et al., MS 2004) were positively correlated. Males and females showed a similar trend in each area (Fig. 1).

Data on the condition of whole sampled female fish were significantly different in all variable interactions (Table 4B). However, the condition of male fish was significantly different with respect to area, year, season and size range, but not all interactions among factors were significant (Table 4C). Seasonal changes in condition presented remarkable geographical differences. Both sexes improved condition in winter-spring in Div. 3LNO; this improvement occurred in summer (and also in summer-autumn for males) in Flemish Cap; in Svalbard, females increased the condition from summer to winter, and the opposite happened for males (Fig. 2).

Flemish Cap (NAFO Div. 3M). Condition increased with the size in spring-summer, and was more noticeable in females. This index showed high interannual vari- ability in individuals $<20 \mathrm{~cm}$, while it decreased from 1998-2000 and then recovered in individuals $\geq 20 \mathrm{~cm}$ (Fig. 3). There was a significant difference in condition with respect to sex, season, size range and year. Not all interactions among factors were significant (Table 4D).

Grand Bank and Flemish Pass (NAFO Div. 3LNO). Condition showed considerable interannual variability for individuals $<20 \mathrm{~cm}$ and reached a maximum in 1999-2001 for individuals $>20 \mathrm{~cm}$. Condition stage diminished slightly for $40-59 \mathrm{~cm}$ fish size and increased considerably for individuals $\geq 70 \mathrm{~cm}$ (Fig. 4). Condition showed significant differences regarding sex, season, size range and year. Not all interactions among factors were significant (Table 4E).

Svalbard (ICES Div. IIb). Condition steady decreased along the period in individuals $<30 \mathrm{~cm}$, while it had a slight decrease in individuals $\geq 30 \mathrm{~cm}$ in 2000-2001. Female condition increased with size, and the opposite happened for males (Fig. 5). Condition 

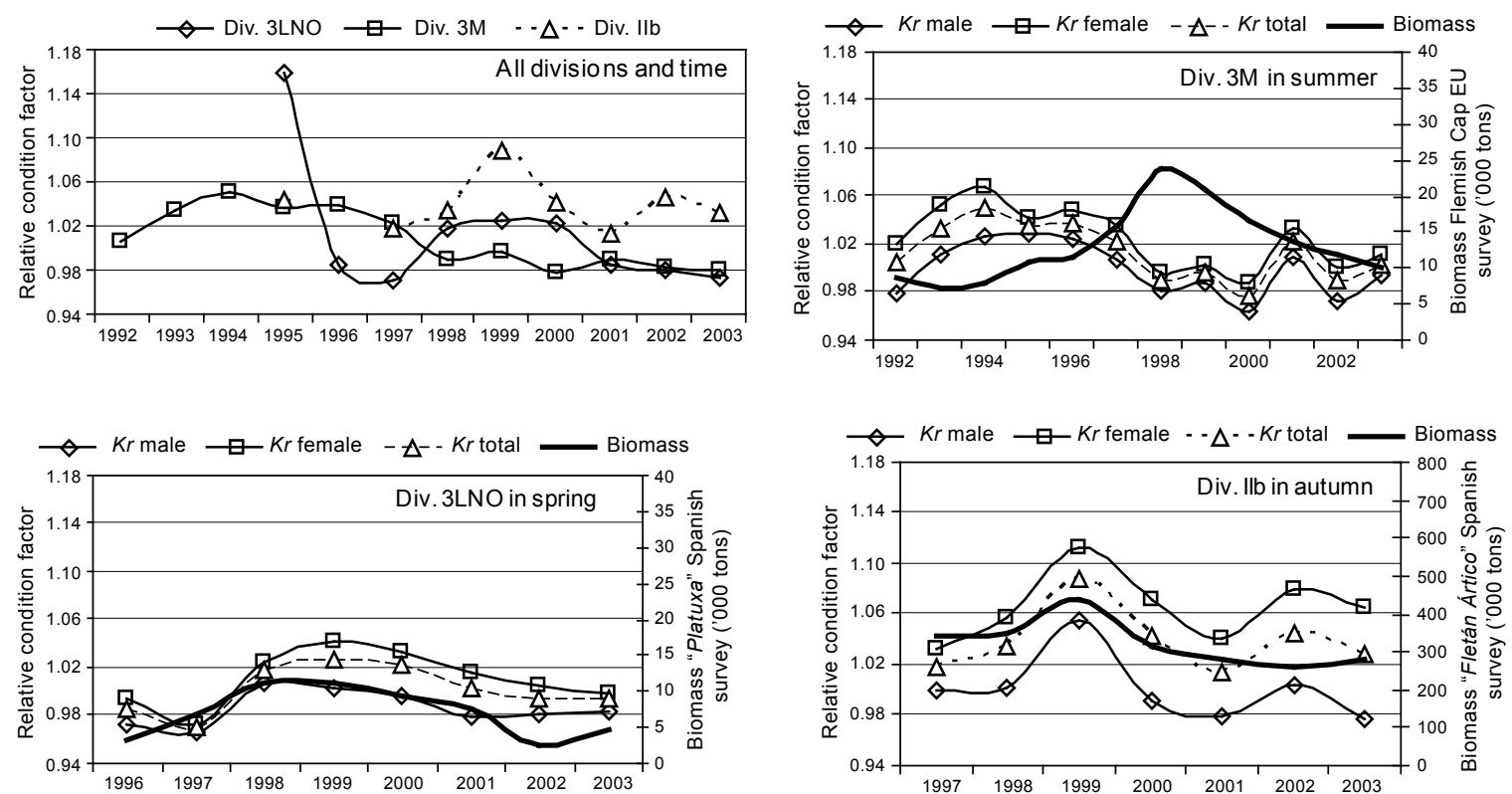

Fig. 1. Mean relative condition factor and biomass estimate of $R$. hippoglossoides by year.
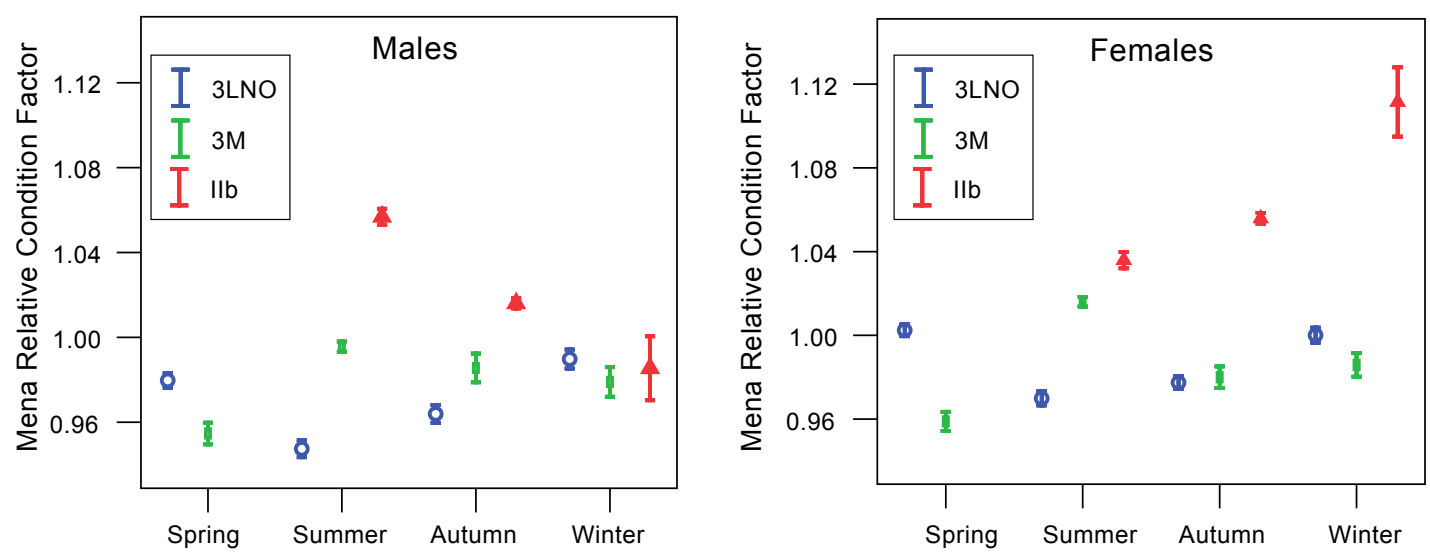

Fig. 2. Relative condition factor (mean and $95 \%$ confidence interval) of $R$. hippoglossoides by sex and season in each area. The sampled periods were: 1992-2003 in NAFO Divisions 3LNO and 3M, and 1995-2003 in ICES Division IIb.

showed significant differences with regard to sex, size range and year. Not all interactions among factors were significant (Table 4F).

Feeding intensity in adult females. Females within the size $\geq 60 \mathrm{~cm}$, most of them mature (Junquera and Saborido-Rey, MS 1995), showed increasing feeding intensity when condition decreased. Feeding intensity increased from spring to winter in Flemish Cap and Div. $3 \mathrm{LNO}$, and decreased from summer to winter in Svalbard (Fig. 6).

\section{Feeding Habits}

Data indicated a high feeding intensity in summer in Div. 3M (62.4\%) and a low one in autumn in Div. IIb (20.4\%) (Table 3). In Div. 3M, the composition of the main prey groups in the diet has virtually suffered no variation during the 1993-2003 period, however an increase of northern shrimp and decrease of fish in the last years has occurred. Pisces (66.4\%) and crustacea $(27.7 \%)$ were the main prey groups (Fig. 7$)$, with Sebastes spp (14.1\%) and northern shrimp (21.8\%) the 
ROMÁN et al: Conditions and Feeding of Greenland Halibut in the North Atlantic
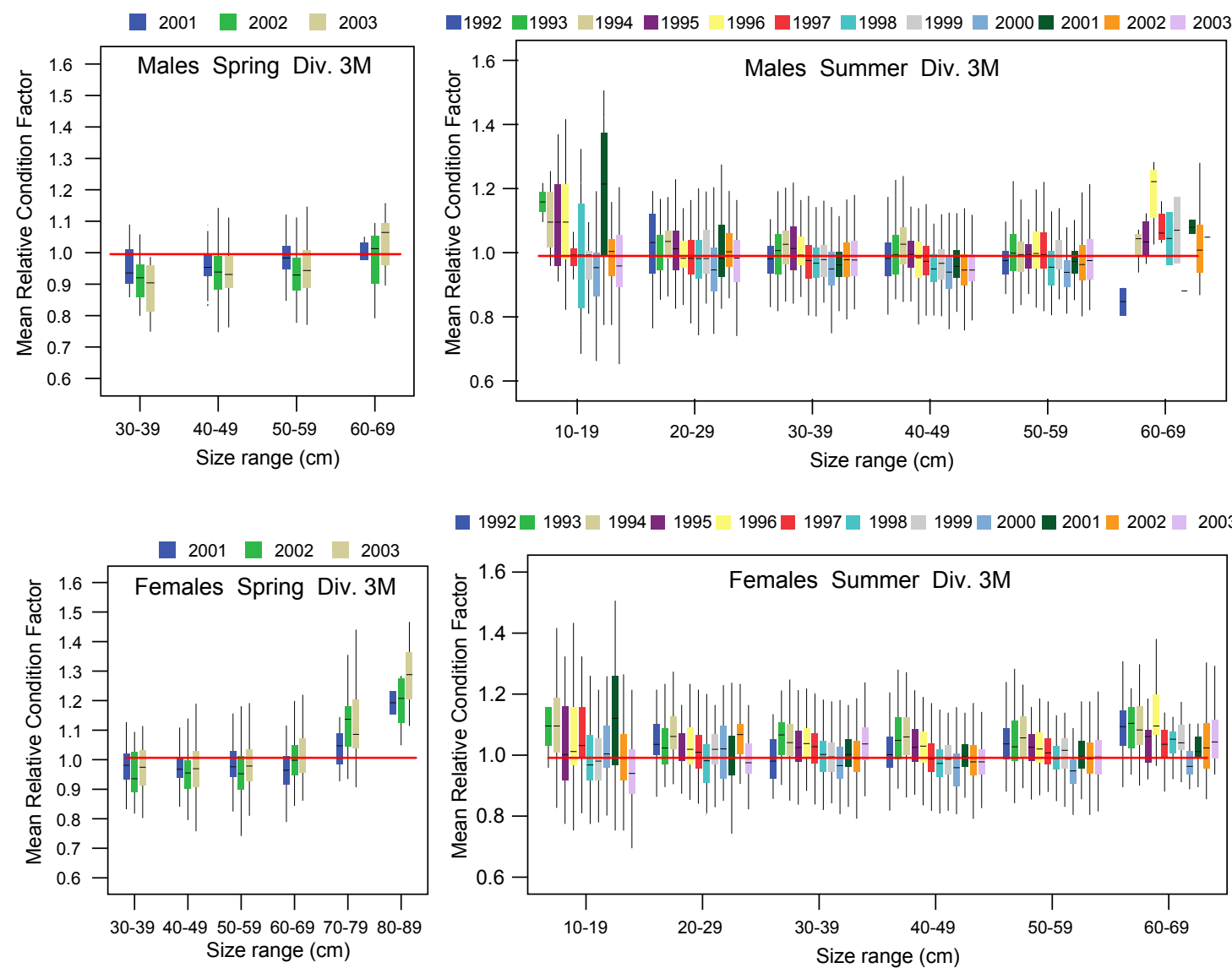

Fig. 3. Mean relative condition factor of $R$. hippoglossoides by year and size range in spring and summer in NAFO Division 3M from 1992 to 2003. Plots show the median (black horizontal line), interquartile (coloured box) and total (black vertical line) range.

species most abundant of these two groups, respectively. Crustacea, mostly hyperiids, predominated in the stomach contents of individuals $<20 \mathrm{~cm}$ and pisces (mainly Sebastes spp and Serrivomer beani) were the principal prey in individuals $\geq 40 \mathrm{~cm}$. Individuals of the size range 20-39 cm had an intermediate level between both diets, increasing the predation on northern shrimp and fish, and decreasing on the hyperiids (Table 5 and Fig. 8).

In Div. 3LNO, there was a higher volume of pisces $(76.7 \%)$ in the diet composition than in the other areas, mainly Mallotus villosus (46.8\%). Crustaceans were not so important in this area, but they were more important than fish in the individuals $<20 \mathrm{~cm}$; and molluscs in intermediate sizes were remarkably important (Table 6, Fig. 8).

In Div. IIb, the diet composition followed a similar pattern. Pisces (66.2\%) and crustacea (12.4\%) were the main prey groups, with Greenland halibut (18.0\%), Micromesistius poutassou (13.6\%) and Pasiphaea tarda $(9.6 \%)$ being the more abundant species in these two groups. Crustacea was the only prey group in individuals $<20 \mathrm{~cm}$, this prey was important until $50 \mathrm{~cm}$ size, and then fish became the main prey for bigger individuals. Molluscs were very abundant in the intermediate sizes (Table 7, Fig. 8).

Offal was a very important food component in Div. IIb $(13.8 \%)$ and it was less important in Div. 3LNO $(3.6 \%)$ where it was found in individuals of bigger size. Cannibalism was observed in Div. IIb (18\%).

Females and males showed similar diet pattern in relation to size in Div. 3M. Females in Div. 3LNO presented more variety of prey than males in sizes $>30 \mathrm{~cm}$. In Div. IIb, differences in the diet composition between 

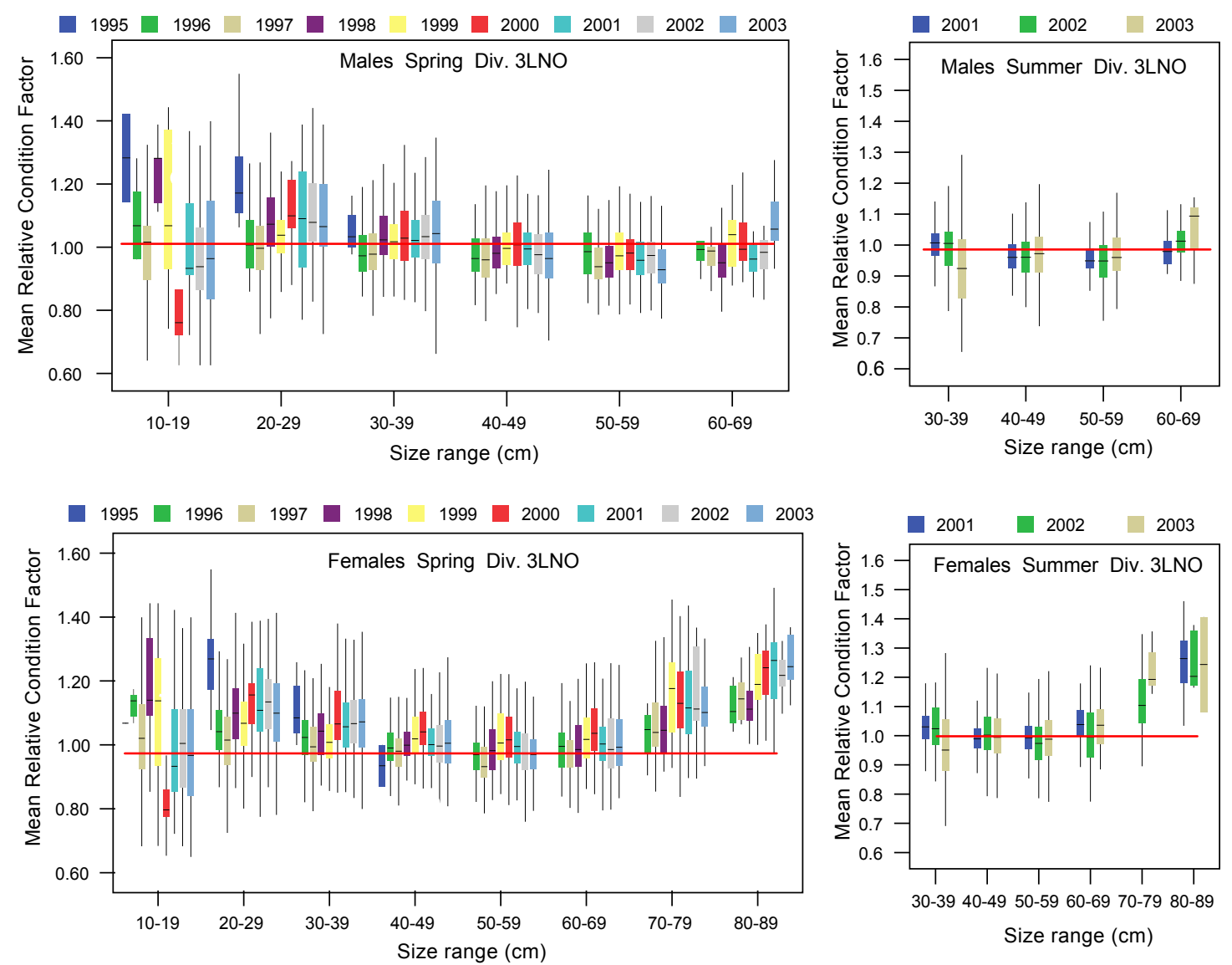

Fig. 4. Mean relative condition factor of $R$. hippoglossoides by year and size range in spring and summer in NAFO Div. 3LNO from 1995 to 2003. Plots show the median (black horizontal line), interquartile (coloured box) and total (black vertical line) range.
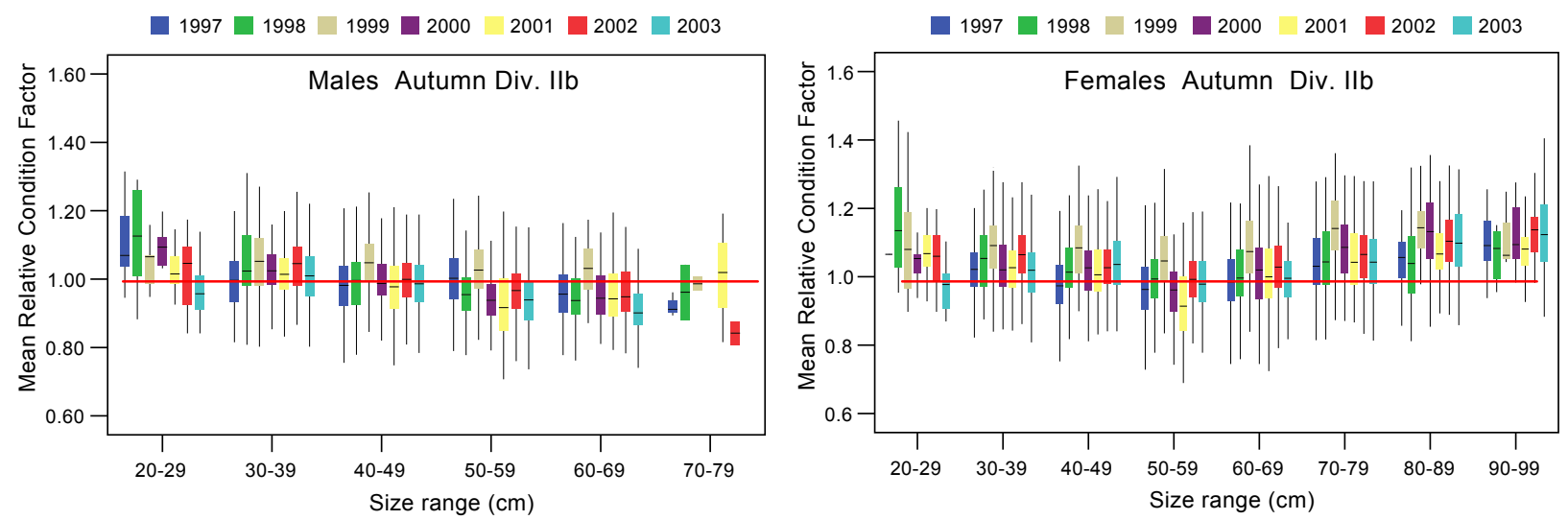

Fig. 5. Mean relative condition factor of $R$. hippoglossoides by year and length in autumn in ICES Division IIb from 1995, 19972003. Plots show the median (black horizontal line), interquartile (coloured box) and total (black vertical line) range. 


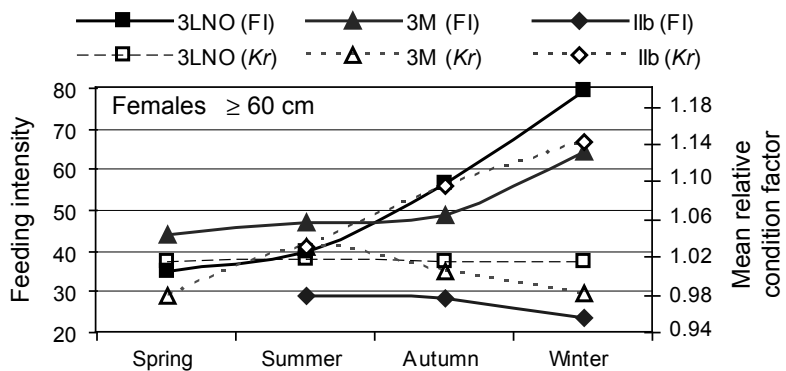

Fig. 6. Percent feeding intensity (FI) and mean relative condition factor $(\mathrm{Kr})$ of adult females $(\geq 60 \mathrm{~cm})$ of $R$. hippoglossoides by area and season.

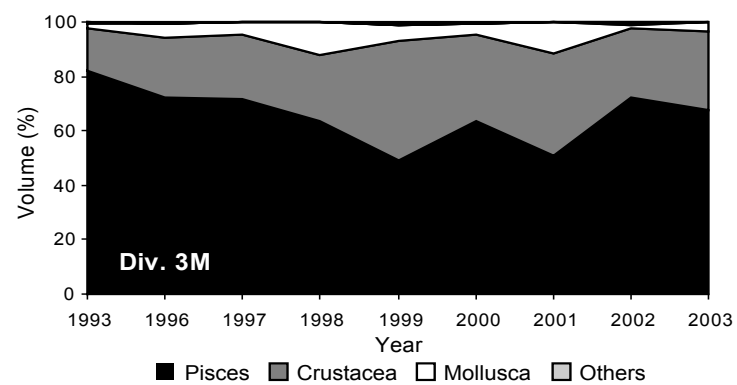

Fig. 7. Volume percent of the main prey groups for R. hippoglossoides by year in Flemish Cap (Div. 3M), 19932003.

TABLE 5. Volume percent of the main prey of $R$. hippoglossoides by size range in Flemish Cap (Div. 3M, 1993-2003).

\begin{tabular}{|c|c|c|c|c|c|c|c|c|c|c|}
\hline \multirow{2}{*}{\multicolumn{2}{|c|}{ Prey }} & \multicolumn{8}{|c|}{ Size Range $(\mathrm{cm})$} & \multirow[b]{2}{*}{ Total } \\
\hline & & $<20$ & $20-29$ & $30-39$ & $40-49$ & $50-59$ & $60-69$ & $70-79$ & $80-89$ & \\
\hline \multirow[t]{11}{*}{ PISCES } & & 2.0 & 8.6 & 41.6 & 65.3 & 84.5 & 92.6 & 91.1 & 100 & 66.4 \\
\hline & Sebastes spp. & & 0.4 & 1.8 & 10.8 & 23.0 & 23.2 & 91.1 & 45.3 & 14.1 \\
\hline & Serrivomer beani & & 1.6 & 5.4 & 12.2 & 14.0 & 30.3 & & & 11.6 \\
\hline & Chauliodus sloani & & & 3.1 & 2.6 & 1.4 & & & & 2.0 \\
\hline & Lycodes sp. & & & 1.1 & 1.5 & 1.0 & & & & 1.1 \\
\hline & Nezumia bairdi & & 0.7 & 2.4 & 3.0 & 5.6 & 0.1 & & & 3.4 \\
\hline & Anarhichas sp. & & 0.2 & 0.3 & 1.5 & 1.5 & 3.3 & & 45.3 & 2.0 \\
\hline & Anarhichas lupus & & 0.0 & 0.3 & 1.1 & 0.4 & 9.2 & & & 1.0 \\
\hline & Lumpenus lumpretaeformis & 1.1 & 0.8 & 3.1 & 1.0 & 0.3 & 0.2 & & & 1.1 \\
\hline & Lampadena speculigera & & & 2.8 & 6.1 & 10.3 & 2.4 & & & 6.2 \\
\hline & Other Pisces & 0.9 & 4.9 & 21.2 & 25.6 & 27.0 & 24.0 & & 9.4 & 23.9 \\
\hline \multicolumn{2}{|l|}{ CRUSTACEA } & 86.3 & 85.6 & 48.9 & 28.4 & 11.5 & 7.0 & & & 27.7 \\
\hline & Hyperiidea & 62.3 & 38.9 & 8.2 & 1.3 & 0.2 & & & & 3.8 \\
\hline & Pandalus borealis & 12.2 & 42.5 & 38.1 & 24.9 & 9.8 & 6.4 & & & 21.8 \\
\hline & Other crustaceans & 11.8 & 4.1 & 2.6 & 2.2 & 1.5 & 0.6 & & & 2.1 \\
\hline \multicolumn{2}{|c|}{ MOLLUSCA } & 11.1 & 3.8 & 8.6 & 5.9 & 3.7 & 0.2 & 8.9 & & 5.4 \\
\hline & Illex coindetii & 1.3 & 0.6 & 2.6 & 1.2 & 0.0 & & & & 1.0 \\
\hline & Decapoda Cephalopoda & 5.3 & 2.2 & 3.6 & 1.6 & 0.8 & & & & 1.7 \\
\hline & Other Mollusca & 4.5 & 1.0 & 2.4 & 3.0 & 2.9 & 0.2 & 8.9 & & 2.7 \\
\hline \multicolumn{2}{|c|}{ ECHINODERMATA } & & 0.0 & 0.1 & 0.0 & 0.1 & & & & 0.0 \\
\hline \multicolumn{2}{|c|}{ OTHER INVERTEBRATES } & 0.6 & 2.0 & 0.5 & 0.2 & 0.1 & 0.1 & & & 0.3 \\
\hline \multicolumn{2}{|l|}{ OTHER } & 0.1 & & 0.3 & 0.2 & 0.2 & 0.1 & & & 0.2 \\
\hline \multicolumn{2}{|c|}{ No. indivs. with stomach contents } & 907 & 719 & 1430 & 1796 & 628 & 40 & 4 & 2 & 5526 \\
\hline
\end{tabular}


TABLE 6. Volume percent of the main prey of $R$. hippoglossoides by size range in NAFO (Div. 3LNO, 2002-03).

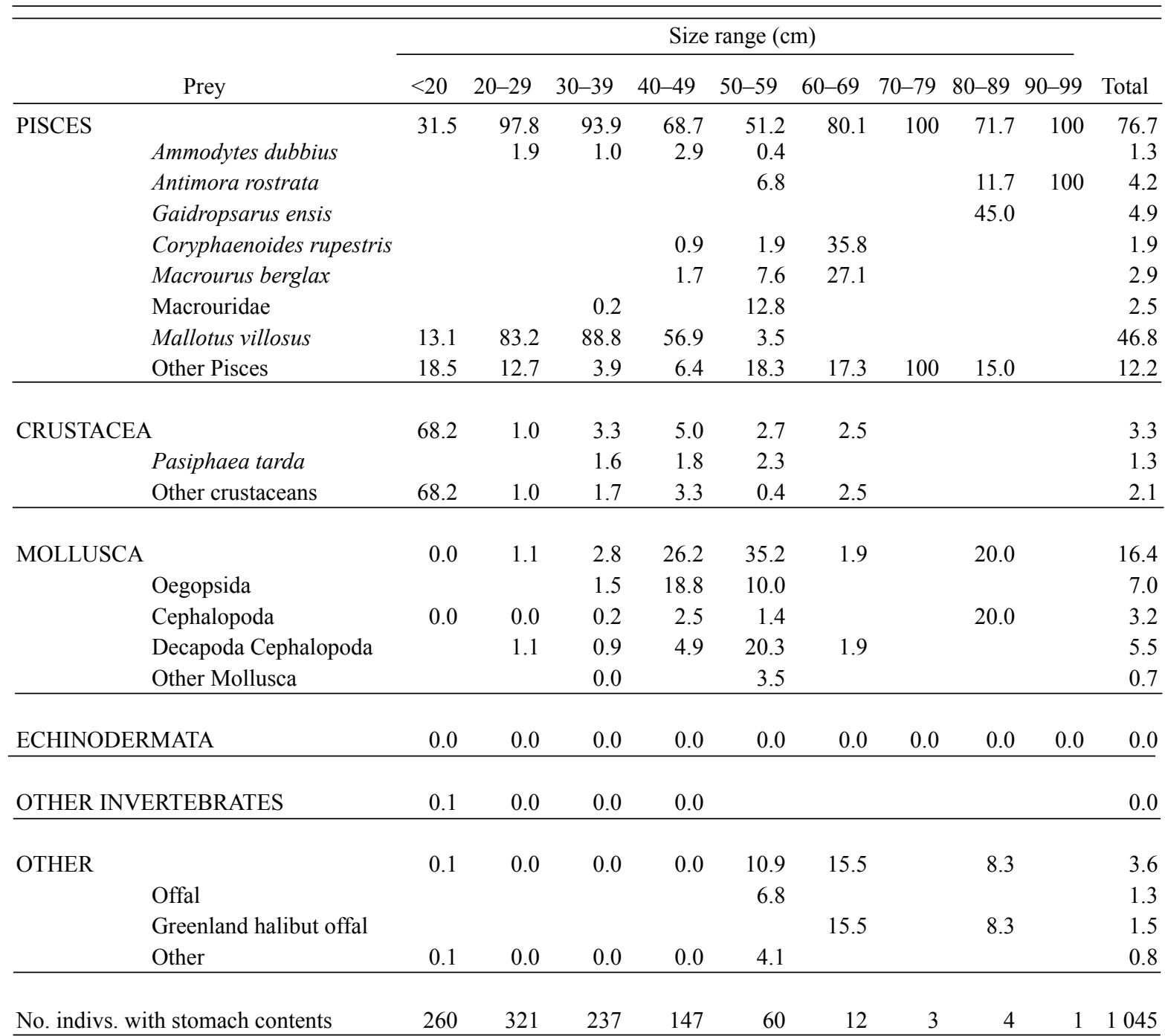

sexes were more important; males preyed more on crustacea than females, and females fed more on molluscs (Fig. 9).

\section{Discussion}

It can be concluded that there were no remarkable differences among Greenland halibut populations regarding condition and feeding habits in the considered Northwest and Northeast Atlantic areas: NAFO Div. 3LMNO and ICES Div. IIb. Results from Bowering and Nedreaass (2001) on age validation and growth of the Northwest and Northeast Atlantic populations suggested that the growth patterns between the two regions might be converging to a similar pattern in recent years. Genetic studies carried out on individuals of different areas of the North Atlantic did not reveal any significant inter-area differences (Vis et al.,
1997; Igland and Nævdal, 2001). This could be related to their highly migratory behaviour over extreme distances, deduced from migratory experiments (Boje, 2001).

Several studies have analysed the condition stage and biological parameters relationship, and their implication in the stock status. Poor condition in Atlantic cod was related with an increase in the natural mortality and low reproductive potential (Dutil and Lambert, 2000; Lambert and Dutil, 2000) and skipped of spawning (Jørgensen et al., 2006). Low condition is common during the spawning season (N'Da and Déneil, 1993). In American plaice (H. platessoides), condition factor and feeding activity decreased in the spawning season (Maddock and Burton, 1999); this fact can be caused by reserve mobilization of somatic energy to carry out the reproduction. 

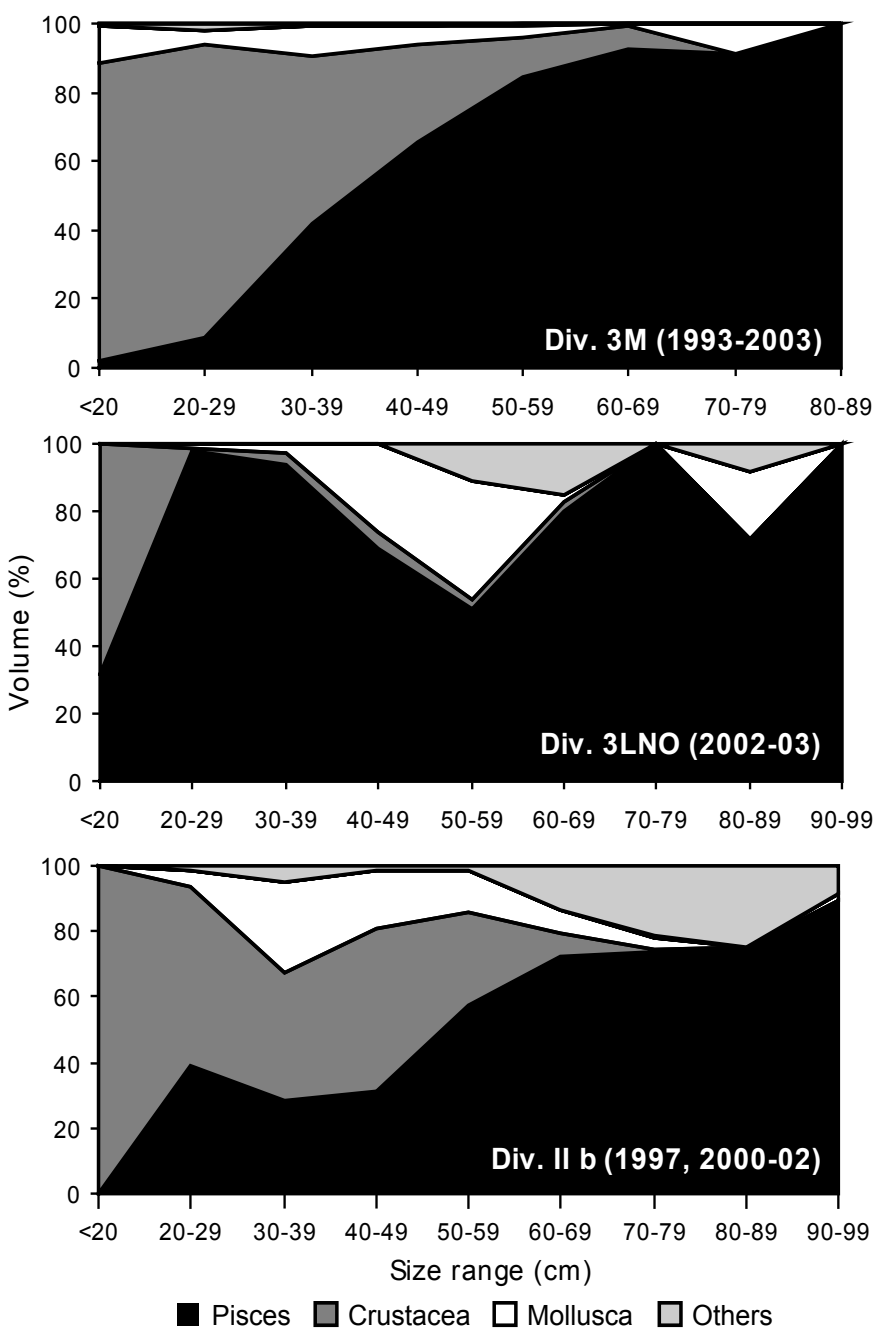

Fig. 8. Volume percent of the main prey groups by size range for $R$. hippoglossoides in NAFO (Divs. 3M, 1993-2003; and 3LNO, 2002-2003) and ICES (Div. IIb, 1997 and 20002002).

Junquera et al. (1999) analysed the Greenland halibut condition in the Northwest Atlantic, from 1991 to 1997, with regard age and year, and they did not found any differences. Nevertheless, significant differences in condition were observed in our study with regard factors such as the geographical area, year, season, size and sex; but the interactions among these variables were not always significant. Similar differences were observed in American plaice (Morgan, MS 2003; González et al. 2006).

Greenland halibut in the Northeast Atlantic (Svalbard) had better condition, mainly noted in females. Peak spawning of Greenland halibut is observed in November-January in the Northeast Arctic, Barents
Sea and West Greenland (Gundersen et al., MS 2001; Simonsen and Gundersen, MS 2002). However, individuals distributed in the Northwest Atlantic (NAFO area) showed a steady decrease of condition throughout the studied period; it was more accused in Flemish Cap. Interannual variation of condition was reflected in the estimated biomass evolution, except in Flemish Cap. In this area, the strong 1995 annual class (Casas and González Troncoso, MS 2003) resulted in a high biomass level in 1998-2000. The high abundance could cause the poor condition observed in those years due to competition.

Changes in feeding habits also have influence on the condition stage. Greenland halibut is mainly a piscivo- 
TABLE 7. Volume percent of the main prey of $R$. hippoglossoides by size range in Div. IIb (ICES, 1997 and 2000-02).

\begin{tabular}{|c|c|c|c|c|c|c|c|c|c|c|c|}
\hline \multirow{2}{*}{\multicolumn{2}{|c|}{ Prey }} & \multicolumn{9}{|c|}{ Size Range $(\mathrm{cm})$} & \multirow[b]{2}{*}{ Total } \\
\hline & & $<20$ & $20-29$ & $30-39$ & $40-49$ & $50-59$ & $60-69$ & $70-79$ & $80-89$ & $90-99$ & \\
\hline \multirow[t]{11}{*}{ PISCES } & & & 38.8 & 28.3 & 31.4 & 57.6 & 72.2 & 73.9 & 74.7 & 89.4 & 66.2 \\
\hline & Sebastes mentella & & & & & 2.0 & 4.2 & 5.6 & 6.5 & & 3.9 \\
\hline & Sebastes sp. & & & & & & & 1.7 & 10.1 & & 1.8 \\
\hline & Micromesistius poutassou & & & 17.4 & 19.2 & 22.6 & 14.4 & 9.8 & 8.4 & & 13.6 \\
\hline & Hippoglossoides platessoides & & & & & & & 1.3 & 4.2 & & 1.0 \\
\hline & Cottunculus microps & & & & & & 3.0 & & 4.6 & & 1.2 \\
\hline & Reinhardtius hippoglossoides & & & & 0.0 & 1.9 & 2.0 & 33.2 & 24.3 & 82.5 & 18.0 \\
\hline & Gaidropsarus argentatus & & & & & 5.0 & 4.3 & & & & 1.8 \\
\hline & Clupea harengus & & & & 0.5 & & 1.6 & 1.7 & 2.8 & & 1.3 \\
\hline & Lycodes sp. & & & & 0.8 & 6.0 & 8.1 & 7.2 & 1.4 & & 5.4 \\
\hline & Other Pisces & & 38.8 & 10.9 & 10.9 & 20.0 & 34.6 & 13.3 & 12.4 & 6.9 & 18.3 \\
\hline \multicolumn{2}{|c|}{ CRUSTACEA } & 100 & 54.8 & 38.7 & 49.3 & 27.9 & 7.5 & 0.7 & 0.6 & & 12.4 \\
\hline & Pasiphaea tarda & & 7.1 & 26.1 & 40.5 & 21.1 & 5.9 & 0.4 & 0.4 & & 9.6 \\
\hline & Other crustaceans & 100 & 47.7 & 12.6 & 8.8 & 6.8 & 1.6 & 0.3 & 0.2 & & 2.8 \\
\hline \multicolumn{2}{|c|}{ MOLLUSCA } & & 5.3 & 28.1 & 17.7 & 13.4 & 6.7 & 3.7 & 0.0 & 2.1 & 7.5 \\
\hline & Oegopsida & & & 14.9 & 6.6 & 0.9 & 0.9 & 2.7 & & & 2.2 \\
\hline & Unidentified Cephalopoda & & & 6.7 & 7.2 & 7.1 & 1.8 & 0.7 & 0.0 & & 2.7 \\
\hline & Unidentified Octopoda & & & 2.4 & 3.2 & 3.3 & 2.5 & 0.3 & & & 1.5 \\
\hline & Other mollusca & & 5.3 & 4.1 & 0.8 & 2.1 & 1.6 & 0.1 & & 2.1 & 1.0 \\
\hline \multicolumn{2}{|c|}{ ECHINODERMATA } & & & & & 0.0 & 0.0 & & & & 0.0 \\
\hline \multicolumn{2}{|c|}{ OTHER INVERTEBRATES } & & & & & 0.0 & 0.1 & 0.2 & & & 0.1 \\
\hline \multirow[t]{3}{*}{ OTHER } & & & 1.1 & 4.9 & 1.6 & 1.1 & 13.5 & 21.5 & 24.7 & 8.5 & 13.8 \\
\hline & Greenland halibut offal & & & & & 0.9 & 12.5 & 21.2 & 23.4 & 8.5 & 13.0 \\
\hline & Other & & 1.1 & 4.9 & 1.6 & 0.2 & 1.0 & 0.4 & 1.3 & & 0.8 \\
\hline \multicolumn{2}{|c|}{ No. indivs. with stomach contents } & 1 & 9 & 147 & 432 & 465 & 301 & 160 & 45 & 8 & 1568 \\
\hline
\end{tabular}

rous predator (Fig. 7), redfish (Sebastes spp.) has been an important prey in Flemish Cap (Table 5) (Román et al., MS 2004). However, predation on fish decreased and predation on crustaceans increased (mainly on northern shrimp) from 1998 to 2001 (Fig. 7). This means an energy density loss (Lawson et al., 1998) that might influence in condition.

Seasonal differences in condition were found for both sexes. In Div. 3LNO, maximum occurred in winter-spring and minimum in summer, for both sexes. In Flemish Cap, maximum occurred later, in summer-autumn, and the minimum in spring, so the gradual decrease of condition is prolonged through a wider period, from summer to winter. Seasonal changes were more difficult to interpret in Svalbard. Females had the highest condition in winter, so the condition recovery would begin earlier in southern latitudes and it would be delayed in northern latitudes. Nevertheless, the process was not coincident for males. These differences would be related to the complex maturity behaviour of Greenland halibut (Bowering and Nedreaas, 2001; Morgan et al., 2003). No clear spawning seasonality was reported in Barents Sea (Federov, 1971a; Albert et al., MS 1998) and Northwest Atlantic (Junquera and Zamarro, 1994; Junquera and Saborido-Rey, MS 1995), besides high inter-annually variability was observed in the spawning peak (Morgan and Bowering, 1997). There is evidence that some mature females do not spawn annually and that the pause in reproduction could last for at least two years (Federov, 1971b). The prolonged 

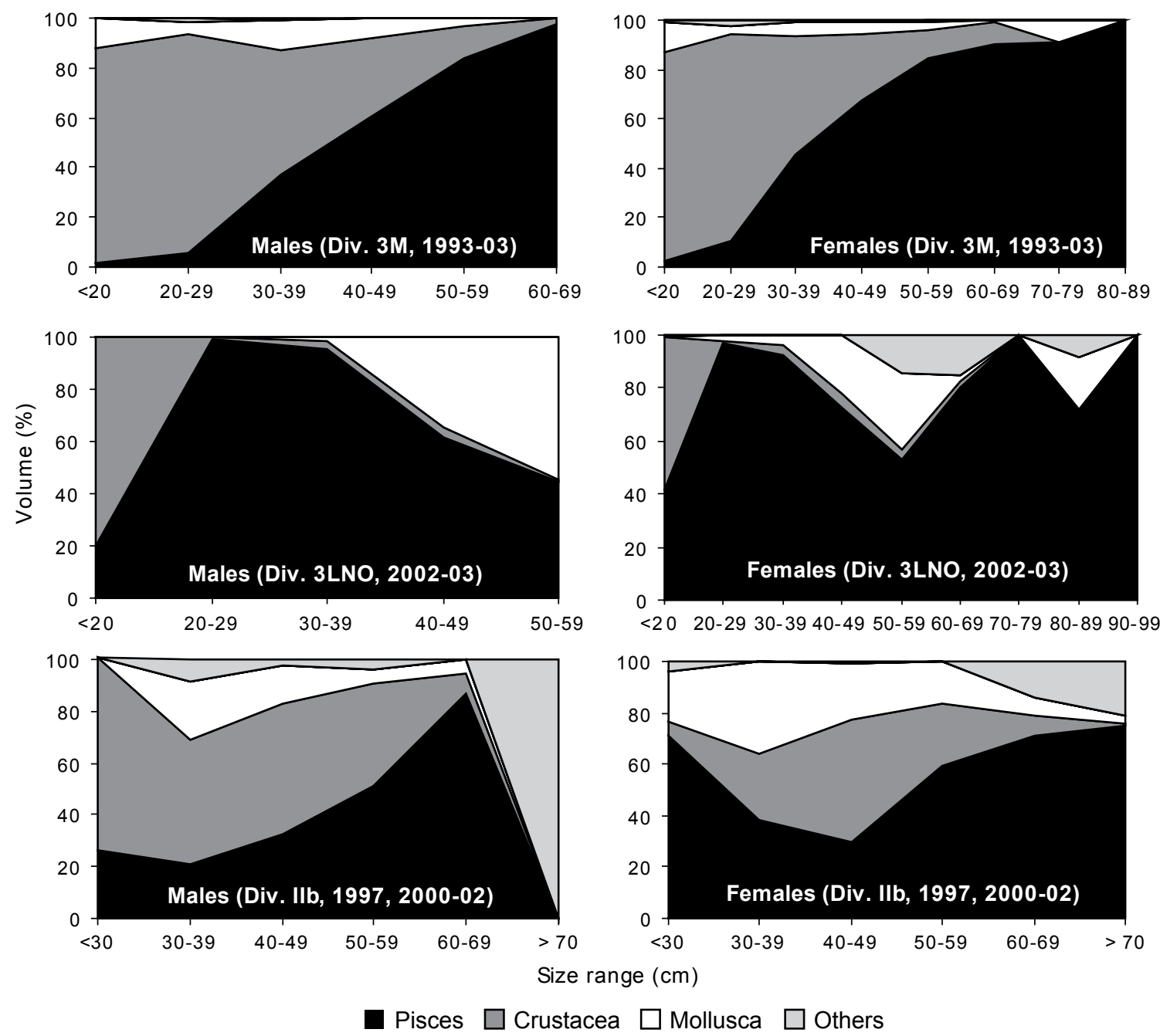

Fig. 9. Volume percent of the main prey groups by size range and sex for $R$. hippoglossoides in NAFO (Div. 3M, 1993-2003; and 3LNO, 2002-2003) and ICES (Div. IIb, 1997 and 2000-2002).

vitellogenesis process could explain the irregularity or lack of clear seasonality in the spawning season in the Northwest Atlantic (Junquera et al., MS 2001), while in the Northeast Atlantic, spawning is more synchronized, with peaks occurring in the last quarter of the year (Albert et al., MS 1998).

We cannot attribute the seasonal and geographical differences in condition (Fig. 2) to the maturation process exclusively, because mature and immature individuals were analysed jointly. Maturity of Greenland halibut is highly variable with regard to size and age (Morgan and Bowering, MS 2000), which would mask differences (geographical, seasonal, on size and sex) in condition.

Condition and feeding activity decrease in the spawning time (Maddock and Burton, 1999). Rodríguez-Marín et al. (MS 1997) founded decreased feeding intensity of Greenland halibut when females become reproductively active. We have used total weight data to calculate condition factor, and gonads and stomach content represent an important part of total weight. We founded a clear opposite trend between condition and feeding intensity in adult females. Seasonal feeding intensity would be dependent of the condition stage. A clear seasonal feeding being not observed, mainly in individuals $<50 \mathrm{~cm}$ (juvenile individuals) in Flemish Pass (Junquera, 1995; Rodríguez-Marín, MS 1995) and West of Greenland (Pedersen and Riget, 1993) would be related with the lack of seasonality at spawning mentioned above.

Interannual in Div. IIb, influenced by the ecosystem characteristics and sampling season (spring-summer $v s$. winter). Higher feeding intensity in the Northwest 
Atlantic than in Northeast has been already reported for other species (González et al., 2006). Piscivorous patterns were similar in the three areas, but the precise prey item changed depending on distribution and availability. Greenland halibut $<20 \mathrm{~cm}$ fed almost exclusively on crustaceans, mainly hyperiids. Predation on crustaceans decreased and fish predation increased when predator size increased. Offal is an extra supply for food introduced by fishing activity (Rodríguez-Marín et al., MS 1997), mainly in larger fish diet in Svalbard. Occasional incidence of echinoderms and other bottom organisms is indicative of the bathypelagic habits of the Greenland halibut (Chumakov and Podrazhanskaya, 1986).

Greenland halibut condition showed some spatial, seasonal and temporal differences. The repercussions in the population stage seem clear, because condition, feeding intensity, food components and reproductive cycle should be closely linked, and even closer in adults. Nevertheless, life history of Greenland halibut is not very well-known, making it difficult to establish conclusive relationships between condition and biological parameters. However, other analyses with eviscered weight could be carried out to obtain more information on the seasonal condition of the individuals.

\section{Acknowledgements}

This work was possible with the support of the Instituto Español de Oceanografía (IEO) and the Secretaría General de Pesca Marítima (SGPM). The authors would like to thank the scientific observers on board of commercial fishing vessels and participant staff in the survey.

\section{References}

Albert, O. T., E. M. Nilssen, A. STEne, A. C. GUNDERSEN, and K. H. NEDREAAS. MS 1998. Spawning of the Barents Sea/Norwegian Sea Greenland halibut (Reinhardtius hippoglosssoides). ICES C.M. Doc., $\mathrm{O}: 22,19 \mathrm{p}$.

BOJE, J. 2001. Intermingling and seasonal migrations of Greenland halibut (Reinhardtius hippoglossoides) populations determined from tagging studies. Fish. Bull., 100: 414-422.

BOWERING, W. R, and K. H. NEDREAAS. 2001. Age validation and growth of Greenland halibut (Reinhardtius hippoglossoides (Walbaum)): A comparison of populations in the Northwest and Northeast Atlantic. Sarsia, 86: 53-68.

CASAS, J. M. MS 2004. Results from bottom trawl survey on Flemish Cap of July 2003. NAFO SCR Doc., No. 21, Serial No. N4969, 36 p.

CASAS J. M., and D. GONZÁLEZ TRONCOSO. MS 2003. Informe de la Campaña de Investigación Pesquera Flemish Cap 2003. Instituto Español de Oceanografía, Vigo, $137 \mathrm{p}$.
COSTOPOULOS, C. G., and M. FONDS. 1989. Proximate body composition and energy content of plaice (Pleuronectes platessa) in relation to the condition factor. Neth. J. Sea Res., 24: 45-55. doi:10.1016/0077-7579(89)90169-5

CHUMAKOV, A. K., and S. G. PODRAZHANSKAYA. 1986. Feeding of Greenland halibut (Reinhardtius hippoglossoides) in the Northwest Atlantic. NAFO Sci. Coun. Studies, 10: 47-52.

DURÁN, P., and E. ROMÁN. MS 2000. Spanish experimental fishings: a cooperative research initiative between scientifics and the local fishing industry. ICES CM 2000/W:03.

DUTIL, J. - D., and Y. LAMBERT. 2000. Natural mortality from poor condition in Atlantic cod (Gadus morhua). Can. J. Fish. Aquat. Sci., 57: 815-825. doi:10.1139/cjfas-574-826

FEDEROV, K. 1971a. The state of the gonads of the Barents Sea Greenland halibut (Reinhardtius hippoglossoides (Walb.)) in connection with the failure to spawn. J. Ichthyol., 11: 673-682.

1971b. Zoogeographic characteristics of the Greenland halibut (Reinhardtius hippoglossoides (Walbaum)). J. Ichthyol., 11: 971-976.

GONZÁLEZ, C., E. ROMÁN, and X. PAZ. 2006. Condition and Feeding of American plaice (Hippoglossoides platessoides) in the North Atlantic with Emphasis on the Flemish Cap. J. Northw. Atl. Fish. Sci., 37: 87-102. doi:10.2960/J.v37. $\mathrm{m} 556$

GONZÁLEZ TRONCOSO, D., E. ROMÁN, and X. PAZ. MS 2004. Results for Greenland halibut from the surveys conducted by Spain in the NAFO Regulatory Area of Div. 3NO, 1996-2003. NAFO SCR Doc., No. 11, Serial No. N4956, $16 \mathrm{p}$.

GUNDERSEN, A. C., O. S. KJESBU, K. H. NEDREAAS, and O. T. ALBERT. MS 2001. Maturity of northeast Arctic Greenland halibut (Reinhardtius hippoglosssoides). NAFO SCR Doc., No. 158, Serial No. N4552, 7 p.

HYSLOP, E. J. 1980. Stomach contents analysis a review of methods and their application. J. Fish. Biol., 17: 411-429. doi:10.1111/j.1095-8649.1980.tb02775.x

ICES. MS 2004. Report of the Arctic Fisheries Working Group. ICES CM 2004/ACFM:28.

IGLAND, O. T., and G. NÆVDAL. 2001. Allozyme studies of Greenland halibut, Reinhardtius hippoglossoides Walbaum 1792, from the North Atlantic. Sarsia, 86: 237-240.

JØRGENSEN, CH., B. ERNANDE, Ø. FIKSEN, and U. DIECKMANN. 2006. The logic of skipped in fish. Can. J. Fish. Aquat. Sci., 63: 200-211.

JUNQUERA, S. 1995. Effect of the feeding activity on the match rates in the Greenland halibut (Reinhardtius hippoglossoides) fishery in Flemish Pass Area (1991-92). NAFO Sci. Coun. Studies, 23: 55-64.

JUNQUERA, S., E. ROMÁN, J. MORGAN, M. SAINZA, and G. RAMILO. MS 2001. Time scale of ovarian maturation in Greenland halibut. NAFO SCR Doc., No.124, Serial No. N4512, 11 p.

JUNQUERA, S., E. ROMÁN, X. PAZ, and G. RAMILO. 1999. Changes in Greenland halibut growth, condition and fecundity in the Northwest Atlantic (Flemish Pass, Flemish Cap and Southern Grand Bank). J. Northw. Atl. 
Sci., 25: 17-28.

JUNQUERA, S., and F. SABORIDO-REY. MS 1995. Histological assessment of sexual maturity in Greenland halibut in Div. 3LM and 3N. NAFO SCR Doc., No. 28, Serial No. N2537, 9p.

JUNQUERA, S., and J. ZAMARRO. 1994. Sexual maturity and spawning of Greenland halibut (Reinhardtius hippoglossoides) from Flemish Pass Area. NAFO Sci. Coun. Studies, 20: 47-52.

LAMBERT, Y., and J.-D. DUTIL. 1997a. Condition and energy reserves of Atlantic cod (Gadus morhua) during the collapse of the Northern Gulf of St. Lawrence stock. Can. J. Fish. Aquat. Sci., 54: 2388-2400. doi:10.1139/cjfas-5410-2388

1997b. Can simple condition indices be used to monitor and quantify seasonal changes in the energy reserves of Atlantic cod (Gadus morhua)? Can. J. Fish. Aquat. Sci., 54 (Suppl. 1): 104-112. doi:10.1139/cjfas-54-S1-104

2000. Energetic consequences of reproduction in Atlantic cod (Gadus morhua) in relation to spawning level of somatic energy reserves. Can. J. Fish. Aquat. Sci., 57: 815-825. doi:10.1139/cjfas-57-4-815

LAWSON, J. W., A. M. MAGALHÃES, and E. H. MILLER. 1998. Important prey of marine vertebrate predators in the northwest Atlantic: proximate composition and energy density. Mar. Ecol. Prog. Ser., 164: 13-20.

LE CREN, E. D. 1951. The length-weight relationship and seasonal cycle in gonad weight and condition in the perch (Perca fluviatilis). J. Anim. Ecol., 20: 201-219. doi: $10.2307 / 1540$

MADDOCK, D. M., and M. P. M. BURTON. 1999. Gross and histological observations of ovarian development and related condition changes in American plaice. J. Fish Biol., 53: 928-944. doi:10.1111/j.1095-8649.1998.tb00454.x

MORGAN, M. J. MS 2003. A preliminary examination of variability in condition of American plaice in NAFO Divisions 3LNO. NAFO SCR Doc., No. 11, Serial No. $\mathrm{N} 4817,14 \mathrm{p}$.

MORGAN, M. J., and W. R. BOWERING. 1997. Temporal and geographic variation in maturity at length and age of Greenland halibut (Reinhardtius hippoglossoides) from the Canadian Northwest Atlantic with implications for fisheries management. ICES J. Mar. Sci., 54: 875-885. doi:10.1006/jmsc.1996.0200

MORGAN, M. J., and W. R. BOWERING. MS 2000. Maturity at age and size of Greenland halibut (Reinhardtius hippoglossoides) and geographic distribution of spawning fish. NAFO SCR Doc., No. 6, Serial No. N4225, 15 p.

MORGAN, M. J., W. R. BOWERING, A. C. GUNDERSEN, Å. HØINES, B. MORIN, O. SMIRNOV, and E.
HJÖRLEIFSSON. 2003. A comparison of the maturation of Greenland halibut (Reinhardtius hippoglossoides) from populations throughout the north Atlantic. J. Northw. Atl. Fish. Sci., 31: 99-112.

MURPHY, B. R., D. W. WILLIS, and T. A. SPRINGER. 1991. The Relative Weight Index in Fisheries management: status and needs. Fisheries, 16: 30-38. doi:10.1577/15488446(1991)016<0030:TRWIIF > 2.0.CO;2

NAFO. MS 2005. Scientific Council Reports 2004. NAFO, Dartmouth, N.S., 298 p.

N'DA, K., and C. DÉNEIL. 1993. Sexual cycle and seasonal changes in the ovary of the red mullet, Mullus surmuletus, from the southern coast of Brittany. J. Fish Biol., 43: 229-244.

OLASO, I. 1990. Distribución y abundancia del megabentos invertebrado en fondos de la plataforma cantábrica. Bol. Inst. Esp. Oceanogr. Publ. Esp., No. 5, 128 p.

PAZ, X., C. GONZÁLEZ, and E. ROMÁN. MS 2004. Spanish bottom trawl survey "Fletán Ártico 2003" in the slope of Svalbard Area, ICES Division IIb. ICES, Arctic Fisheries Working Group, 2004, Working Doc. 22, 19 p.

PEDERSEN, S. A., and F. RIGET. 1993. Feeding habits of redfish (Sebastes spp.) and Greenland halibut (Reinhardtius hippoglossoides) in West Greenland waters. ICES. J. Mar. Sci., 50: 445-459. doi:10.1006/jmsc.1993.1048

RODRIGUEZ-MARÍN, E., A. PUNZÓN, J. PAZ and I. OLASO. MS 1994. Feeding of the most abundant fish species in Flemish Cap in summer 1993. NAFO SCR Doc., No. 35, Serial No. N2403, 33 p.

RODRÍGUEZ-MARÍN, E. MS 1995. Feeding Relationships of Demersal Fish in Flemish Cap in Summer, 1993-1994. NAFO SCR Doc., No. 104, Serial No. N2627, 15 p.

RODRÍGUEZ-MARÍN, E., E. DE CÁRDENAS, and J. PAZ. MS 1997. Feeding of Greenland halibut (Reinhardtius hippoglossoides) in 3LMNO NAFO Regulatory Area Divisions (Northwest Atlantic), 1991-94. NAFO SCR Doc., No.37, Serial No. N2869, 10 p.

ROMÁN, E., C. GONZÁLEZ, and E. CEBALLOS. MS 2004. Food and Feeding of Most Abundant Fish Species in Flemish Cap. NAFO SCR Doc., No. 58, Serial No. N5018, $17 \mathrm{p}$.

SIMONSEN, C. S., and A. C. GUNDERSEN. MS 2002. Maturity of Greenland halibut (Reinhardtius hippoglossoides) in the Fjords of northwest Greenland. NAFO SCR Doc., No. 38, Serial No. N4649, 12 p.

VIS, M. L., S. M. CARR, W. R. BOWERING, and W. S. DAVIDSON. 1997. Greenland halibut (Reinhardtius hippoglossoides) in the North Atlantic are genetically homogeneous. Can. J. Fish. Aquat. Sci., 54: 1813-1821. doi:10.1139/cjfas-54-8-1813 